\title{
Upwelling shadows at Mejillones Bay (northern Chilean coast): a remote sensing in situ analysis
}

\author{
Víctor H. Marín ${ }^{1}$, Luisa E. Delgado ${ }^{1}$ \& Rubén Escribano ${ }^{2}$ \\ ${ }^{1}$ Laboratorio de Modelación Ecológica, Depto. Ciencias Ecológicas, Facultad de Ciencias \\ Universidad de Chile, Casilla 653, Santiago, Chile \\ ${ }^{2}$ Centro de Investigación Oceanográfico en el Pacífico Sur-Oriental, COPAS \\ Universidad de Concepción, Casilla 160-C, Concepción, Chile \\ E-mail: vmarin@antar.uchile.cl
}

\begin{abstract}
Upwelling shadows are high temperature regions within coastal upwelling systems. In this article its dynamics is described at Mejillones Bay, in the northern Chilean coast, using satellite images and in situ current data. A conceptual model relating the generation and breakdown of the shadow to the bifurcated upwelling occurring outside the bay is proposed.
\end{abstract}

Key words: coastal upwelling, satellite images, upwelling shadows.

\section{Sombras de surgencia en la bahía de Mejillones (costa norte de Chile): un análisis por medio de sensoramiento remoto y muestreo in situ}

RESUMEN. Las sombras de surgencia son regiones de alta temperatura al interior de sistemas de surgencia costera. En este artículo se describe su dinámica en la bahía de Mejillones, en la costa norte de Chile, usando imágenes satelitales y correntometría in situ. Se propone un modelo conceptual que relaciona la generación y el rompimiento de la sombra con la surgencia bifurcada que ocurre al exterior de la bahía.

Palabras claves: surgencia costera, imágenes satelitales, sombras de surgencia.

\section{INTRODUCTION}

Coastal upwelling is one of the most important oceanographic processes generating cold-water, nutrient-rich patches and filaments in Eastern Boundary Currents (Strub et al., 1998). The spatial variability of this process, as affected by coastline geometry and bottom topography, produces highly heterogeneous environments (Strub et al., 1991). This heterogeneity may include anomalously high temperature regions known as upwelling shadows (UPS). UPS are meso-scale circulation features occurring in rather specific coastal areas: convex coastlines, downstream of capes or headlands. Although their dynamics is not entirely clear, they occur in sectors of reduced wind forcing, where upwelled water warms up rapidly generating a thermal front (Graham \& Largier, 1997). The tem- poral dynamics of an UPS is related to the water flows generated during the spin-up/spin-down phases of upwelling events (Send et al., 1987). They are produced during the spin-up phase and its persistence, however, will depend upon the strength and duration of the spin-down phase (Graham \& Largier, 1997).

Upwelling shadows, given their enhanced residence times, have been proposed as playing a disproportionately significant role in the ecology of coastal areas (Graham et al., 1992; Graham \& Largier, 1997). For example, Graham \& Largier (1997) at Monterey Bay and Wing et al. (1998) off Point Reyes, both located within the California current system, have shown that UPS play an important role in the coastal retention of 
meroplanktonic larvae. Only recently, Marín et al. (2001) have documented their presence during the spring-summer season at Mejillones Bay; an equator-facing bay off the northern end of Mejillones Peninsula at the Chilean coast. The authors suggest that the higher temperature found inside the bay, even during active upwelling, agree with the presence of a shadow. The main goal of this article is to describe the short-term temporal dynamics of this upwelling shadow using a mixture of satellite images and in situ data.

\section{METHODS}

\section{SST satellite image analysis}

Upwelling shadows generate a surface temperature signature (i.e. an area of high temperature within an upwelling system) that can be detected through
AVHRR sensors (Graham \& Largier, 1997). A total of 200 NOAA's AVHRR images (pixel size $=1.1$ $\mathrm{km}$ ) from the northern Chilean coast were analyzed. Daily images, recorded during spring-summer 1998 through 2000, were transferred from the Centro de Estudios Espaciales (CEE) of Universidad de Chile to the Laboratorio de Modelación Ecológica for its analysis. Channel-4 irradiance was used to generate sea surface temperature grids. The calibration algorithm (CALINOAA) was provided by the CEE. All images were rectified (using ERDAS Imagine 8.5) and stored for subsequent analysis using a geographic information system (ARC/INFO).

\section{Current measurements inside the shadow}

An Aanderaa RCM9 currentmeter was anchored inside Mejillones Bay to study the subtidal variability of the coastal flow and its relationship with the development of the upwelling shadow (Fig.

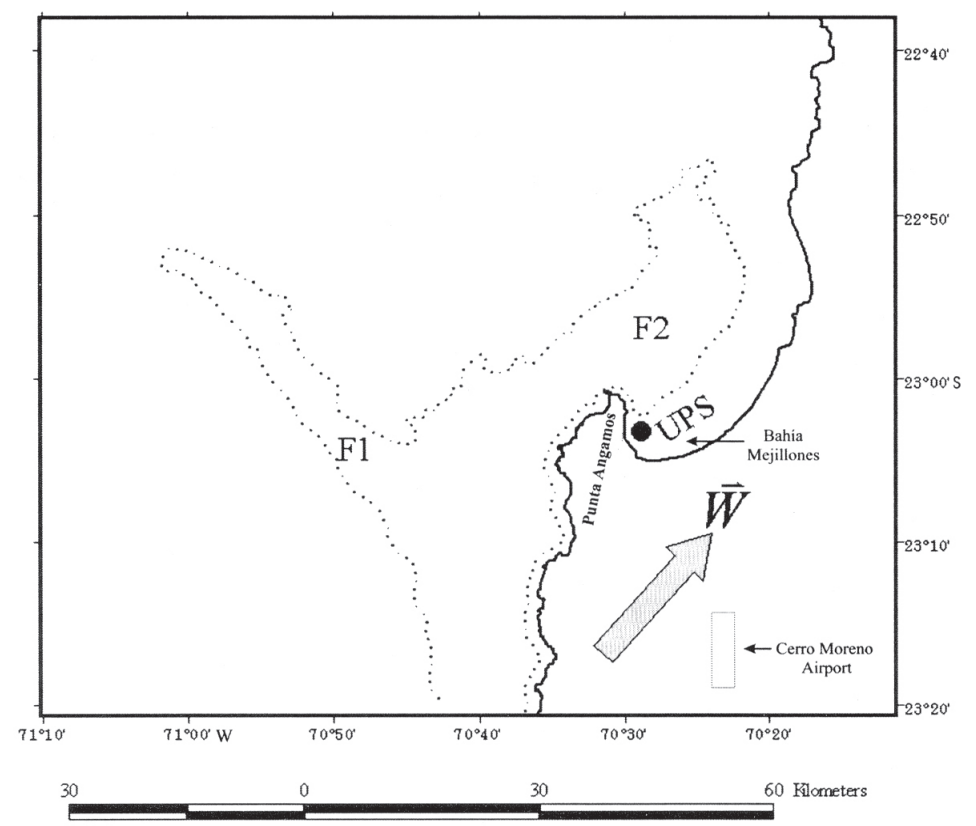

Figure 1. Scheme of the distribution of cold water filaments observed during spring-summer 1998-2000 in the Mejillones Bay region (dashed line). Filaments (F1 and F2) are generated during the spin-up phase of upwelling events. UPS: upwelling shadow. The figure also shows the location of Cerro Moreno Airport. The arrow shows the dominant wind direction. The black dot shows the anchoring point of the current meter.

Figura 1. Esquema de la distribución de filamentos fríos durante la primavera-verano 1998-2000 en la región de la Bahía de Mejillones (línea entrecortada). Los filamentos (F1 y F2) son generados durante la fase de aceleración de los eventos de surgencia. UPS: sombra de surgencia. La figura también muestra la localización del Aeropuerto Cerro Moreno. La flecha muestra la dirección dominante del viento. El punto negro muestra el sitio de anclaje del correntómetro. 
1). The RCM9 was anchored at a depth of $15 \mathrm{~m}$, measuring current speed and direction, temperature and dissolved oxygen at hourly intervals for a month (Nov. 28 - Dec. 28 1998). Tidal (semidiurnal and diurnal) and higher frequency components were removed using a low-pass filter, leaving all components with periods larger than 25 hours. The temporal variability of local forcing was also studied using the wind records from Cerro Moreno Airport. Daily averages of the N-S (alongshore) component of wind velocity were calculated from the available hourly data. Increases in equatorward speed were considered as indicative of spin-up and decreases as indicative of spin-down conditions. Two upwelling events were identified within the studied period. The first occurred between December $7^{\text {th }}$ and $14^{\text {th }}$, the second between December $21^{\text {st }}$ and $26^{\text {th }}$ (Fig. 2).

\section{Assessment of the biological effects of the upwelling shadow}

The potential influence of the upwelling shadow on the primary production of Mejillones Bay was studied using two methods: (1) analysis of two SeaWIFS images, one at the beginning of the main upwelling event (Dec.07.1998), and the other at the end of it (Dec.15.1998); and (2) using the oxygen data from the current meter records. Chlorophyll-a was estimated from SeaWIFS L1A images using the software provided by NASA (SEADAS 4.0p3). A non-linear function (Systat\%o 7.0 non-linear regression) was generated in order to relate surface chlorophyll-a, CHLA ( $\left.\mathrm{mg} \cdot \mathrm{m}^{-3}\right)$ to the euphotic zone integrated primary production, IPP $\left(\right.$ ton $\left.\mathrm{C} \cdot \mathrm{km}^{-2} \cdot \mathrm{d}^{-1}\right)$. Published local data was used for both variables (Marín et al., 1993; Marín \& Olivares, 1999). The resulting function was:

$$
\mathrm{IPP}=0.65 \cdot \mathrm{CHLA}^{0.74} \quad\left(\mathrm{r}^{2}=0.44, \mathrm{n}=40\right),
$$

IPP was then estimated from the SeaWIFS images using equation 1 . This method assumes that there is no bias or error in the chlorophyll estimates from the SeaWIFS satellite. Thus, it's been used for comparative purposes only (before/after upwelling shadow). Finally, apparent oxygen utilization, AOU (Strickland \& Parsons, 1972), was used to estimate changes in the metabolism of Mejillones Bay.
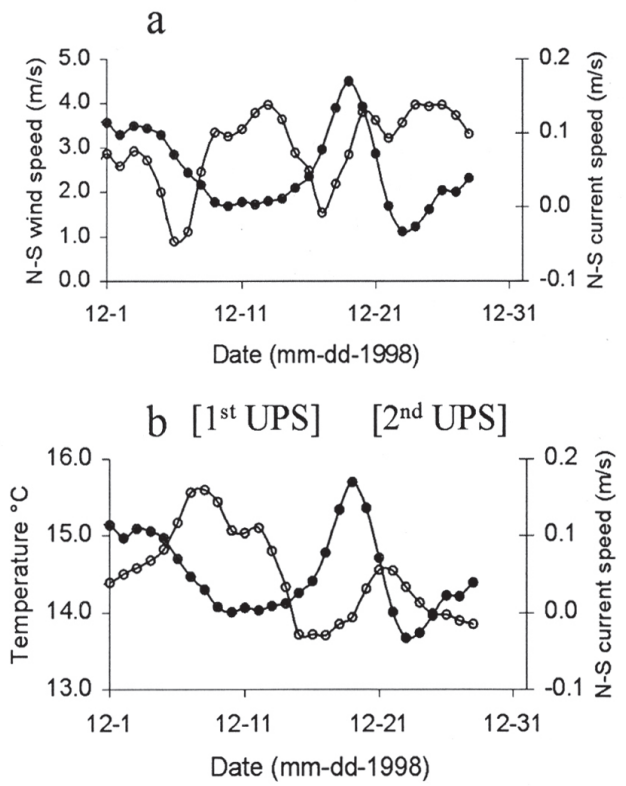

$\mathrm{C}$

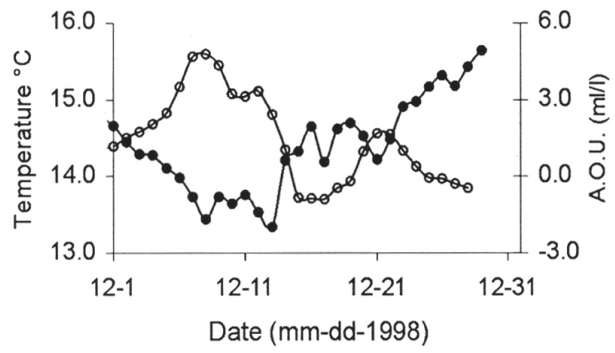

Figure 2. Time series, three-points running averages, of Cerro Moreno's wind and oceanographic variables recorded by the RCM9 current meter. Open circles correspond to left-y-axis, dark circles to right-y-axis. a) $\mathrm{N}-\mathrm{S}$ component of wind (left-y-axis) and current velocity (right-y-axis), b) temperature (left-y-axis) and current velocity (right-y-axis), c) temperature (left $y$ axis) AOU (right y-axis).

Figura 2. Series de tiempo, promedio móvil de peso tres, del viento medido en Cerro Moreno y de variables oceanográficas registradas por el correntómetro RCM9. Los círculos abiertos corresponden al eje y izquierdo, los oscuros al eje y derecho. a) componente $\mathrm{N}-\mathrm{S}$ del viento (eje vertical izquierdo) y velocidad de la corriente (eje vertical derecho), b) temperatura (eje vertical izquierdo) y velocidad de la corriente (eje vertical derecho), c) temperatura (eje vertical izquierdo) y AOU (eje vertical derecho). 


\section{RESULTS}

\section{SST satellite images}

Five images have been included (Appendix I) as examples of the recurrent SST patterns found during spring-summer (1998-2000). Figure 1 is a summary drawing of the spatial structure of the upwelling filaments generated at the northern tip of Mejillones Peninsula. The dominant SW winds produce a bifurcated upwelling system at Punta Angamos. Previous observations (Marín et al., 1993) show that the F1 (offshore) filament is generated when the alongshore component of the dominant wind exceeds $5 \mathrm{~m} \cdot \mathrm{s}^{-1}$. However, the F2 (alongshore) filament was observed also at lower wind speeds and is the main generator of the upwelling shadow (UPS in Fig. 1) at Mejillones Bay.

\section{Current measurements}

The temporal evolution of an upwelling event can be divided in two phases (Send et al., 1987): spinup (i.e. when equatorward wind speed is increasing) and spin-down (i.e. when equatorward wind speed is decreasing or it reverses in direction). The result of the analysis of wind and current data is shown in Figure 2. Wind forcing slowed down at the beginning of the study period (Nov. 28 through Dec. 06 1998), with a subsequent spin-up on Dec.07.1998 (N-S wind speed $>3 \mathrm{~m} \cdot \mathrm{s}^{-1}$ ) until Dec.13.1998 (Fig. 2a). During this spin-up phase current measurements and satellite images showed the development of an upwelling shadow inside Mejillones Bay (Fig. 2) and a F2 filament to the north (Fig. 3). Subtidal velocities decreased nearly to zero during the development of the upwelling shadow, remaining in this condition until the spin-down phase started. Recorded temperature increased in $1.2^{\circ} \mathrm{C}$ during the development of the shadow (Fig. 2B). This $\Delta \mathrm{T}^{\circ}$ was consistent with temperature differences calculated from the available sequence of satellite images. The temperature signature of the upwelling shadow ended on Dec.14.1998, when the spin-down phase started. Thus, the shadow at Mejillones Bay persists during the spin-up phase and vanishes during the spin-down phase.

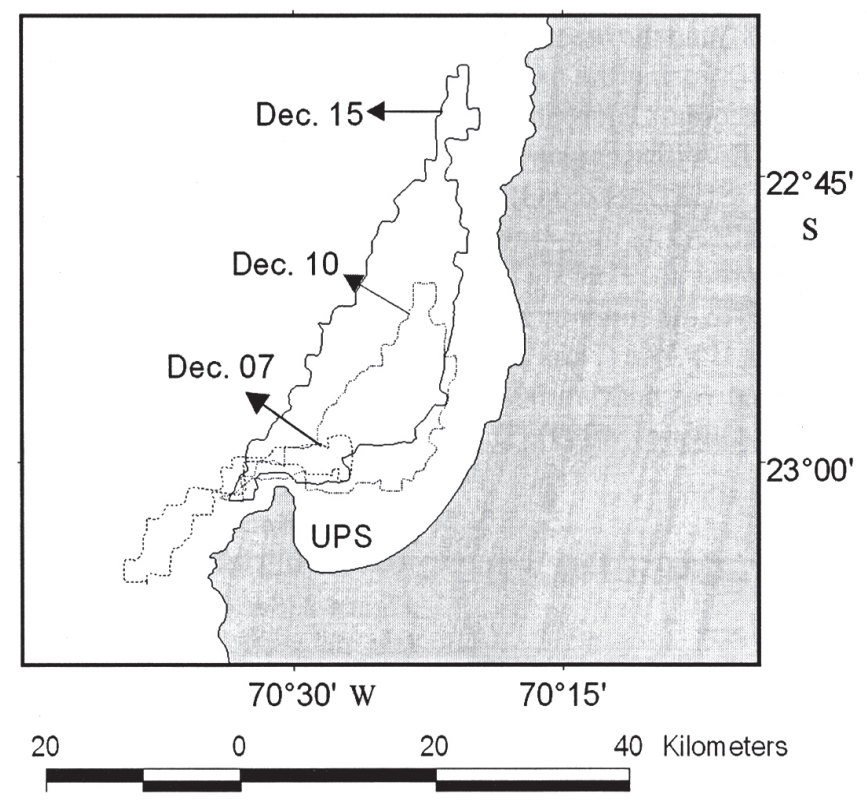

Figure 3. Development of a F2 filament during the $1^{\text {st }}$ UPS (see Fig. 2). The figure shows the time sequence (December $7^{\text {th }}, 10^{\text {th }}$ and $15^{\text {th }}$ ) of the filament, delimited by the $16.5^{\circ} \mathrm{C}$ isotherm (dotted line) at each date, north of Mejillones Bay.

Figura 3. Desarrollo de un filamento F2 durante la primera UPS (ver Fig. 2). La figura muestra la secuencia temporal (Diciembre 7, 10 y 15) del filamento, delimitado por la isoterma de $16,5^{\circ} \mathrm{C}$ en cada fecha, al norte de la bahía de Mejillones. 
Both advection as well as local surface heat flux may have been responsible for the observed increase in temperature during the development of the shadow. Advection was ruled out given the rather low sub tidal velocities (Fig. 2b). Generating the observed $\Delta \mathrm{T}^{\mathrm{o}}$ from surface heat flux was tested using the formula to calculate the shadow residence time, R (Graham \& Largier, 1997):

$$
\mathrm{R}=\rho \cdot \mathrm{c} \cdot \mathrm{H} \cdot \Delta \mathrm{T} / \mathrm{Q}
$$

where $\Delta \mathrm{T}$ is the temperature increase $\left(1.2^{\circ} \mathrm{C}\right), \mathrm{H}$ is the depth of the mixed layer (assumed to be at least $15 \mathrm{~m}$, the depth of current meter deployment), $c$ is the heat capacity of the seawater $\left(3990 \mathrm{~J} \mathrm{C}^{-1} \cdot \mathrm{kg}^{-1}\right), \mathrm{r}$ is the density of seawater $\left(1025 \mathrm{~kg} \mathrm{~m}^{-3}\right)$ and $\mathrm{Q}$ is the daily average surface heat flux under clear skies during November-December in the coastal Atacama region $\left(0.4 \mathrm{~kW} \cdot \mathrm{m}^{-2}\right.$, Data from Meteorological

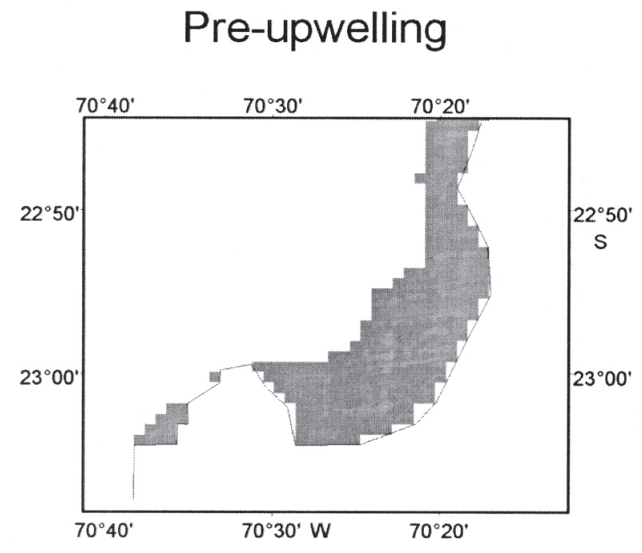

Station of Universidad del Norte, Antofagasta). The observed $\Delta \mathrm{T}$ would have required a $\mathrm{R}$ of only 2-3 days. An alternative way to calculate the residence time of the UPS is using the current meter data. If it is assumed that the shadow persisted during the days when the current meter registered near-zero velocities (Fig. 2b), then the residence time of the first UPS was of the order of 6-7 days.

\section{Biological effects of the upwelling shadow}

The AOU data showed that except for the first upwelling shadow, values were positive reflecting a lack of oxygen (Fig. 2c). Indeed, AOU and temperature showed a significant negative correlation $(r=-0.78 ; p<<0.001)$, suggesting that oxygen super-saturation, most likely due to photosynthesis, is produced only when the UPS is present. In fact, the SeaWIFS-based analysis showed a three-fold increase in primary production within Mejillones Bay, from an average rate of 1.0 ton
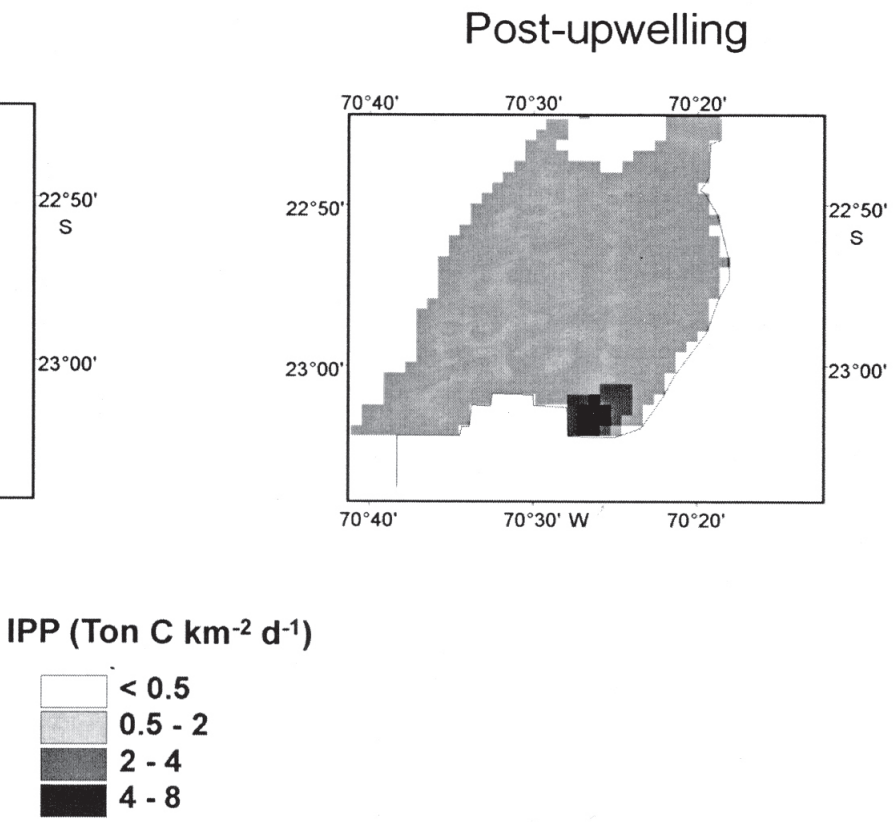

Figure 4. Spatial distribution of euphotic zone integrated primary production (IPP). IPP was estimated from SeaWIFS images and a locally derived chlorophyll-IPP non-linear regression. Pre-upwelling: Dec.07.1998, postupwelling: Dec.15.1998.

Figura 4. Distribución espacial de la producción primaria integrada en la zona eufótica (IPP). IPP fue estimada a partir de imágenes SeaWIFS y de una ecuación de regresión no-lineal derivada de datos locales de clorofila y IPP. Pre-surgencia: Dic.07.1998, post-surgencia: Dic.15.1998. 
$\mathrm{C} \cdot \mathrm{km}^{-2} \cdot \mathrm{d}^{-1}$ before the shadow to higher than 4.0 ton $\mathrm{C} \cdot \mathrm{km}^{-2} \cdot \mathrm{d}^{-1}$ after the shadow (Fig. 4).

\section{DISCUSSION}

The analyses of SST satellite images have shown the development of bifurcated upwelling filaments at Punta Angamos and the generation of an upwelling shadow inside Mejillones Bay. This type of bifurcated flow from an upwelling center has already been described at Monterey Bay in the California Current system (Rosenfeld et al., 1994) and proposed for Tongoy Bay in the Humboldt Current System (Moraga et al., 2001). Figure 5 shows a conceptual model of the relationship between the phases (spinup and spin-down) of an upwelling event and the development of the UPS. The coastal boundary of the F2 filament (see Fig. 3) behaves as a wall (thermal front on Fig. 5), leaking nonetheless, retaining water inside Mejillones Bay. This reduced horizontal transport, together with the low turbulence induced by the reduction of wind forcing inside the bay (the effect of the Peninsula on the dominant equatorward wind), generates an area of low subtidal velocities that warms up due to solar irradiation, generating the UPS. The estimated temperature increase inside the shadow $\left(1.2^{\circ} \mathrm{C}\right)$ is indeed consistent with Graham \& Largier's (1997) calculation for Monterey Bay, who assumed a thermal change due to heating of $0.5^{\circ} \mathrm{C}$ a day ${ }^{-1}$. This result supports an UPS residence time of 2-3 days. However, the alternative estimation of $\mathrm{R}$, using currentmeter data, is more consistent with a longer residence time (7 days).

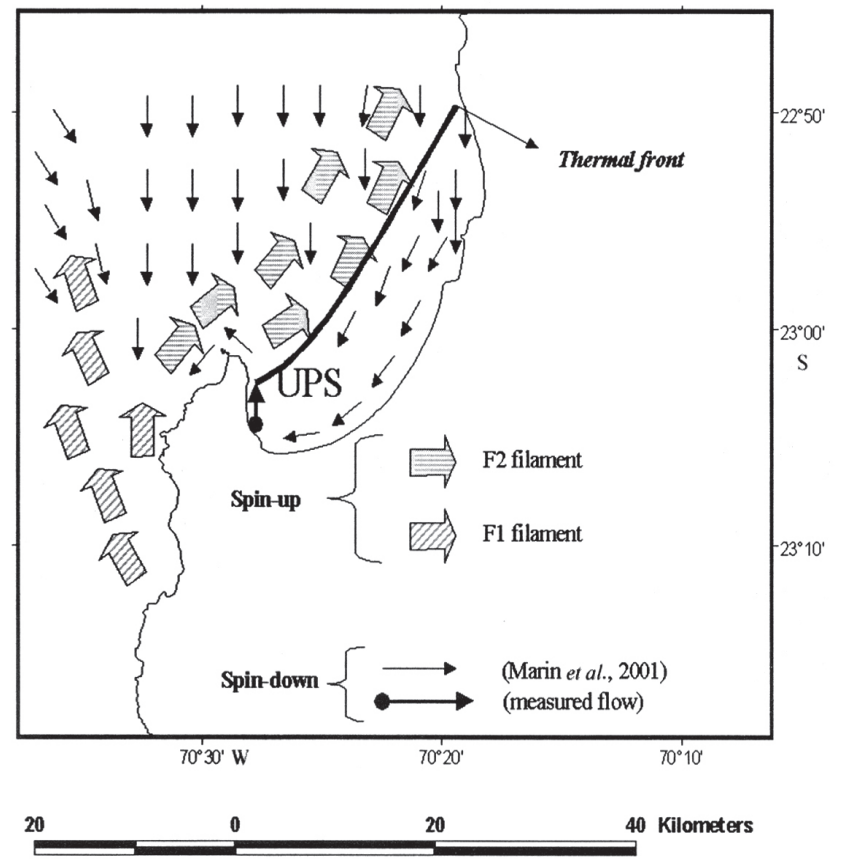

Figure 5. Conceptual model for the generation of the upwelling shadow (UPS) at Mejillones Bay. The increase in equatorward wind, spin-up phase, generates both offshore and onshore upwelling filaments at Mejillones Peninsula (bifurcated upwelling). The thermal front located in the inner side of the onshore filament, together with the wind-protected condition of Mejillones Bay, generates a low velocity area inside the bay that corresponds to the UPS. A decrease in wind speed, spin-down phase, revert the circulation flushing UPS waters out of the bay.

Figura 5. Modelo conceptual para la generación de una sombra de surgencia (UPS) en la bahía de Mejillones. EI aumento en la componente del viento hacia el ecuador, fase de aceleración, genera filamentos de surgencia tanto costa afuera como hacia la costa en la península de Mejillones (surgencia bifurcada). El frente térmico localizado en el lado interno del filamento costero, junto con la condición de protección del viento de la bahía de Mejillones, genera un área de baja velocidad al interior de la bahía que corresponde a la UPS. Una disminución en el viento, fase de desaceleración, revierte la circulación expulsando las aguas UPS fuera de la bahía. 
Applying equation 2 and solving it for $\Delta \mathrm{T}$, using a value for $\mathrm{R}=7$ days, shows that the temperature increase should have been of the order of $4^{\circ} \mathrm{C}$. Thus, if the residence time was indeed longer than 3 days, then the observed $\Delta \mathrm{T}\left(1.2^{\circ} \mathrm{C}\right)$ is likely to be the result of surface heat flux plus diffusion from the F2 filament and/or sub-surface layer. Thus, the UPS behaves as a buoyant parcel of water trapped against the coast. As long as the F2 filament remains in place (spin-up conditions, 3-7 days) the UPS will persist. Coastal flows during spin-down are less known. Most of the evidence suggests that this phase is dominated by alongshore poleward flows especially close to shore (Marín et al., 2001; Mesías et al., 2001; Marín \& Moreno, 2002). This flow, which due to the curvature of the coastline appears as a northward flow in the location where it was measured (Figs. 1 and 2b), effectively marks the end of the UPS. Mejillones Bay is then filled with water from the north, the cold-water dominated sector (see Appendix I). It follows from our conceptual model that the UPS will again be generated at the next spinup phase. In this regard our model differs from Graham \& Largier (1997) conceptualization. They propose that upwelling shadows may indeed persist for weeks. We propose that the shadow at Mejillones Bay is generated during the spin-up phase of an upwelling event and it vanishes during the spin-down phase, unless the later is shorter than 2 days. Indeed, if one considers an alongshore subtidal velocity of ca. $0.2 \mathrm{~m} \cdot \mathrm{s}^{-1}$ (Fig. 2), see also Marín et al. (2001) it would take only 2 days to "flush the bay" with water from the north during the spin-down phase.

The residence time ( 3 to 7 days), low velocity and turbulence, together with the inflow of nutrients either due to lateral mixing with the adjacent F2 filament or from below the euphotic zone (Marín \& Olivares, 1999; Graham \& Largier, 1997), make the UPS an appropriate environment for high levels of biological production and for the retention of planktonic organisms (Olivares, 2001). The results of both AOU data and SeaWIFS images analysis can be interpreted as increases in primary production when the upwelling shadow is present. Evidences from the literature indeed show that Mejillones Bay is a very productive bay (Marín et al., 1993), where high concentrations of zooplankton are normally found (Escribano \& Hidalgo, 2000). Under active upwelling conditions (i.e. spin-up phase) Mejillones Bay may act as an efficient retention zone for planktonic organisms (e.g. Calanus chilensis), allowing the presence of discrete cohorts (Giraldo et al., 2002). The UPS imposes a distinct temperature and food regime (high chlorophyll); variables that influence the growth and development of zooplanktonic organisms (e.g. Escribano et al., 1997). However, since the shadow breaks apart after 4 to 7 days, zooplanktonic organisms developed inside the bay soon would mix with the rest of the population upon the beginning of the spin-down phase. This would explain sudden disappearances of the Calanus population from the bay, as noted by Escribano \& McLaren (1999). Thus, the UPS seem to play an important role in the biological production of Mejillones Bay.

In summary, the upwelling shadow at Mejillones Bay can be understood as the direct consequence of bifurcated coastal upwelling coupled with the presence of a coastal promontory or peninsula that generates an F2, alongshore, filament and an area of low subtidal velocities. It develops during spin-up conditions and it disappears during the spin-down phase. Given the dominance of equatorward winds in the northern Chilean coast (Strub et al., 1998) and the high radiation characteristic of the Atacama Desert coastline, this upwelling-related, small-scale feature is likely to occur year-round at Mejillones Bay.

\section{ACKNOWLEDGEMENTS}

This work was financed by Project FONDECYT 98/ 0366 (CONICYT-Chile) awarded to Rubén Escribano and Víctor Marín. Additional support for this work has been provided by FONDAP COPAS Center

\section{REFERENCES}

Escribano, R. \& P. Hidalgo. 2000. Spatial distribution of copepods in the north of the Humboldt Current region off Chile during coastal upwelling. J. Mar Biol. Ass. U.K., 80: 283-290.

Escribano, R., C. Irribarren \& L. Rodríguez. 1997. Influence of food quantity and temperature on development and growth of Calanus chilensis from northern Chile. Mar. Biol., 128: 281-289.

Escribano, R. \& I.A. McLaren. 1999. Production of Calanus chilensis from the upwelling area of Antofagasta, northern Chile. Mar. Ecol. Prog. Ser., 177: $147-156$. 
Giraldo, A., R. Escribano \& V. Marín. 2002. Spatial distribution and coastal upwelling effects on body size of copepodid stages Calanus chilensis off Mejillones Peninsula, northern Chile. Mar. Ecol. Prog. Ser., 230: 225-234.

Graham, W.M. \& J.L. Largier. 1997. Upwelling shadows as nearshore retention sites: the example of northern Monterey Bay. Cont. Shelf Res., 17: 509-532.

Graham, W.M., J.G. Field \& D.C. Potts. 1992. Persistent "upwelling shadows" and their influence on zooplankton distributions. Mar. Biol., 114: 561570.

Marín, V. \& G.R. Olivares. 1999. Estacionalidad de la productividad primaria en Bahía Mejillones del Sur (Chile): una aproximación proceso-funcional. Rev. Chil. Hist. Nat., 72: 629-641.

Marín, V., L. Rodríguez, L. Vallejo, J. Fuenteseca \& E. Oyarce. 1993. Dinámica primaveral de la productividad primaria de Bahía Mejillones del Sur (Antofagasta, Chile). Rev. Chil. Hist. Nat., 66: 479491.

Marín, V., R. Escribano, L.E. Delgado, G. Olivares \& P. Hidalgo. 2001. Nearshore circulation in a coastal upwelling site off the northern Humboldt Current System. Cont. Shelf Res., 21: 1317-1329.

Mesías, J., R. Matano \& P.T. Strub. 2001. A numerical study of the upwelling circulation off central Chile. J. Geophys. Res., 106: 19611-19623.

Moraga, J., E. Valdebenito \& J. Rutllant. 2001. Condiciones oceanográficas durante la fase de relajación de un evento de surgencia invernal frente a Punta Lengua de Vaca, Coquimbo. Invest. Mar., Valparaíso, 29: 59-71.
Olivares, G. 2001. Mecanismos de interacción físicobiológicas en una zona de surgencia costera: retención de larvas y cierre del ciclo de vida de Euphausia mucronata. M. Sc. Thesis, Universidad de Chile, 80 pp.

Rosenfeld, L.K., F.B. Schwing, N. Garfield \& D.E. Tracy. 1994. Bifurcated flow from an upwelling center: a cold water source for Monterey Bay. Cont. Shelf Res., 14: 931-964.

Send, U., R.C. Beardsley \& C.D. Winant. 1987. Relaxation from upwelling in the coastal ocean dynamics experiment. J. Geophys. Res., 92(C): 1683-1698.

Strickland, J.D.H. \& T.R. Parsons. 1972. A practical handbook of seawater analysis. Fish Res. Board Can., 167: 310 pp.

Strub, P.T., J.M. Mesías, V. Montecino, J. Rutllant \& S. Salinas. 1998. Coastal ocean circulation off western South America. Coastal segment $(6, \mathrm{E})$. In: A.R. Robinson \& K.H. Brink (eds.). The Sea, 11: 273-308.

Strub, P.T., P.M. Kosro \& A. Huyer. 1991. The nature of the cold filaments in the California Current System. J. Geophys. Res., 96: 1474314768.

Wing, S., L. Botsford \& S. Ralston. 1998. Meroplanktonic distribution and circulation in a coastal retention zone of the northern California upwelling system. Limnol. Oceanogr., 43: 17101721. 


\section{APPENDIX I}

\section{SEA SURFACE TEMPERATURE (SST) IMAGES DERIVED FROM NOAA'S AVHRR SENSORS.}

We show below five images to exemplify the patterns of cold-water filaments generated in the Mejillones Peninsula sector. False color represents temperature in ${ }^{\circ} \mathrm{C}$. The first three images correspond to spring condition, the last two to summer condition.
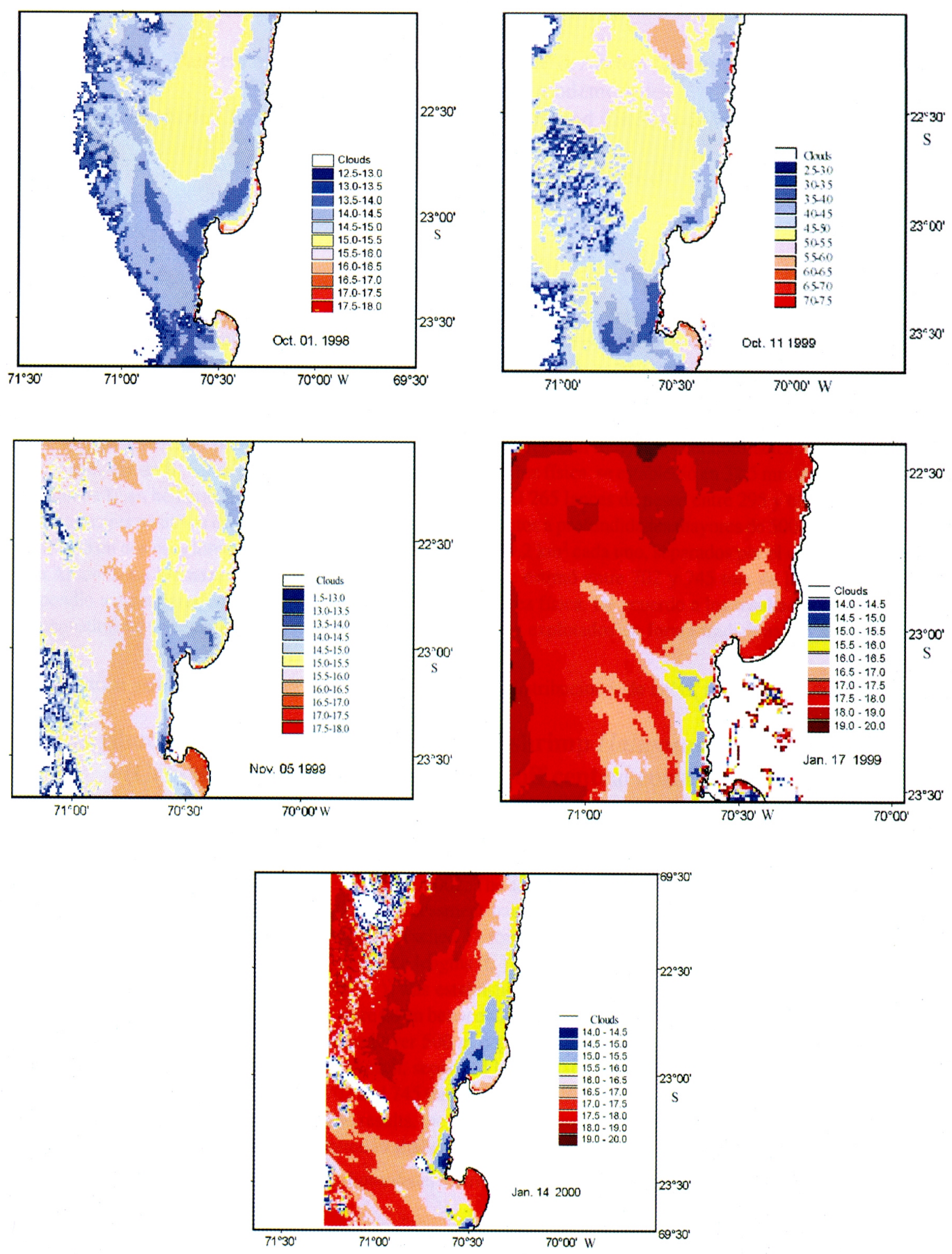